\title{
The Lysosomal Membrane Complex
}

\author{
FOCAL POINT OF PRIMARY STEROID HORMONE ACTION
}

\author{
By CLARA M. SZEGO, BARBARA J. SEELER, ROSEMARIE A. STEADMAN, \\ DIANE F. HILL, ARTHUR K. KIMURA AND JAMES A. ROBERTS \\ Department of Zoology and Molecular Biology Institute, \\ University of California, Los Angeles, Calif. 90024, U.S.A.
}

(Received 5 February 1971)

\begin{abstract}
At short intervals after the intravenous administration of oestradiol-17 $\beta$, diethylstilboestrol, testosterone or saline control solution to ovariectomized rats, highly purified lysosome samples were prepared in substantial yield from preputial glands, sex accessory organs rich in these organelles. The preparations were essentially devoid of mitochondrial contamination. Exposure in vivo to doses of these hormones varying from 0.1 to $5 \mu \mathrm{g} / 100 \mathrm{~g}$ body wt. provoked dose-dependent labilization of the lysosomal membrane surface, as evidenced by significantly diminished structural latency of several characteristic acid hydrolases, including acid phosphatase, $\beta$-glucuronidase and acid ribonuclease II, when such preparations were subsequently challenged in vitro with autolytic conditions, detergent or mechanical stress. Enhanced lytic susceptibility induced by hormone pretreatment was occasionally detectable in the initial preparation without further provocative stimuli in vitro. Comparable results were obtained with the corresponding fractions of uterus, despite the more limited concentration of lysosomes in this steroidal target organ. By the present criteria oestradiol-17 $\alpha$ was essentially inert, even in a dose 25 times that effective for its active $\beta$-epimer $(<0.1 \mu \mathrm{g} / 100 \mathrm{~g}$ body wt.). Pretreatment with diethylstilboestrol exerted substantial membrane-destabilizing influence in preputial-gland lysosome samples from orchidectomized rats. Moreover, administration of testosterone to gonadectomized animals resulted in essentially equivalent dose-dependent augmentation of lysosomal enzyme release in preputialgland preparations of either sex. The membrane stability of lysosome-enriched preparations from uterus, on the other hand, was unaffected by testosterone pretreatment. The sensitivity, specificity and selectivity of the lysosomal response to sex steroids provide evidence for the physiological significance of this phenomenon as a general mechanism for mediation of secondary biochemical transformations in the hormone-stimulated target cell.
\end{abstract}

Evidence has long been available from these laboratories and elsewhere that the trophic influence of many hormones, including those of steroid nature, is linked to acute alterations in membrane function in their specific target cells (Roberts \& Szego, 1953; Hechter, 1955; Hechter \& Halkerston, 1964; Wigglesworth, 1964). Thus within 15s after the administration of oestrogen to ovariectomized rats secondary reflexions of the interaction of the hormone with receptor sites in the uterus were already evident in release of sequestered amines (cf. Szego, 1965) and in stimulation of membrane-bound adenylate cyclase (Szego \& Davis, 1967). Moreover, blockade of the explosive elevation of uterine cyclic AMP (adenosine cyclic $3^{\prime}: 5^{\prime}$-monophosphate) concentration attributable to oestrogen could be effected not only by selected $\beta$-adrenergic blockingagents (Szego \& Davis, 1969a) but also by glucocorticoids (Szego \& Davis, 1969b), both of which possess significant membrane-stabilizing properties. Evidence has been presented that full expression of the manifold secondary responses of steroidal targets to their trophic hormones is dependent on these early actions (Szego, 1965; Griffin \& Szego, 1968). These considerations prompted examination of the acute influence of the steroid hormones on stability of the bounding membranes of subcellular organelles. For reasons provided in detail elsewhere (Szego, 1971a) the lysosomal membrane system was investigated. The present experiments reveal that selected steroid hormones and related hormonally active substances, administered in vivo in microgram 
and submicrogram amounts to gonadectomized rats, exert a surface-active influence on lysosomes subsequently isolated from specific target tissues, with resultant liberation of an array of bound hydrolytic enzymes from sequestration. These observations extend previous data from these laboratories (Szego \& Davis, 1969b; Szego, 1970), and have permitted formulation of a new and comprehensive hypothesis of steroid hormone action based on the propagation of secondary molecular events in the target tissue as a result of primary degradation of a large variety of structural and functional macromolecules (Szego, 1971 $a$ ).

\section{EXPERIMENTAL}

Rats of an inbred Sprague-Dawley strain were maintained on Purina laboratory chow and ovariectomized at 6 weeks of age and approx. $160 \mathrm{~g}$ body wt. For some experiments comparable orchidectomized animals were prepared. They were then kept in a low-steroid environment under standardized conditions of temperature and light for 3 weeks. On the day of experiment the rats were matched by body weight into control and experimental groups. With the rats under light sodium pentobarbital (Nembutal) anaesthesia $(5 \mathrm{mg} / 100 \mathrm{~g}$ body wt.) hormone or control solutions prepared as described by Szego \& Davis (1967) were injected into the saphenous vein.

At timed intervals, usually $15 \mathrm{~min}$ after injection of test substances, appropriate organs were excised rapidly, blotted on Whatman no. 40 filter paper and chilled. Sampling included uteri and paired preputial glands, each set being pooled from ten experimental or control animals. Typical weights of a series of 13 pooled samples from control animals were $0.832 \pm 0.032 \mathrm{~g}$ (mean \pm S.E.M.) for preputial glands and $0.794 \pm 0.027 \mathrm{~g}$ (mean \pm s.E.M.) for uteri. No consistent difference attributable to pretreatment of animals of origin was observed in pooled organ weights. Choice of the preputial gland was prompted by its extraordinarily high $\beta$-glucuronidase activity (Beyler \& Szego, 1954; Levvy, McAllan \& Marsh, 1958) and profusion of lysosomes, as demonstrated by electron-microscopic (R. F. Dunn, D. F. Hill, J. A. Roberts \& C. M. Szego, unpublished work), cytochemical (Smith \& Fishman, 1969) and fluorescence-microscopic procedures (see below).

Lysosome preparations. Tissues were weighed rapidly and then minced with scissors in vessels kept on cracked ice. All subsequent preparative procedures were carried out at $0-4^{\circ} \mathrm{C}$. In some of the initial experiments the tissue mince, as a $10 \%(\mathrm{w} / \mathrm{v})$ suspension in $0.25 \mathrm{M}$-sucrose (Mallinckrodt, A. R.), was homogenized in a calibrated (approx. 550 rev./min) motor-driven Potter-Elvehjem glass homogenizer by using six cycles of $15 \mathrm{~s}$ each separated by $15 \mathrm{~s}$ cooling intervals in the surrounding crushed icewater bath. For uniformity the same homogenizer was used repeatedly within each experiment with appropriate rinsing and chilling between control and experimental samples. In most experiments, however, cell disruption was carried out with a prechilled hydraulic tissue press (Emanuel \& Chaikoff, 1957), obtainable from Microchemical Specialties Co., Berkeley, Calif., U.S.A.

Highly purified lysosome samples were prepared from the resultant homogenates by a centrifugation scheme
(Scheme 1) slightly modified from that of Weissmann \& Thomas (1963). During the separation, washing and resuspension of subcellular constituents every effort was made to avoid undue mechanical agitation of the preparations, which could result in lysosomal damage that could attenuate differences arising from exposure in vivo to hormone. Teflon spatulas and polythene tubes were used throughout. Bulk transfers were carried out by decantation; removal of samples was achieved by the use of wide-bore plastic pipettes.

The hydraulic tissue press, when used as specified, proved greatly superior to the glass homogenizer in providing a higher yield of undamaged lysosomes from the preputial gland, as indicated by the marker enzymes $\beta$-glucuronidase and acid phosphatase (Fig. 1). Thus although essentially equivalent concentrations of these enzymes occurred in the particle-free lysosomal supernatants of both preparations, much less extraneous protein sedimented with fraction LP2 (Scheme 1) in the sample obtained from homogenization with the press. Consequently the specific activities of the lysosomal enzymes were considerably greater in the latter preparation. The results reported below were obtained uniformly on lysosome fractions of homogenates prepared with the special press.

Identity and homogeneity of the lysosome preparations. By analogy with comparable lysosome fractions from liver and kidney, it might be expected that present preparations of these organelles would be grossly contaminated with mitochondria (cf. Vignais \& Nachbaur, 1968). However, fluorescence-microscopy and enzyme-distribution studies indicated that this was not true for the preputial samples at least. For fluorescence microscopy lysosome suspensions were prepared from fraction LP2 (Scheme 1) by gentle dispersion of the pellet in $2 \mathrm{ml}$ of $0.25 \mathrm{M}$-sucrose, portions of which were exposed to the vital dye Acridine Orange (Dingle \& Barrett, 1969). On systematic scanning of a series of such preparations it was observed that discrete red-orange-fluorescing organelles of the symmetry and dimensions characteristic of lysosomes filled every field. Mitochondria, despite the relative infrequency of their occurrence, were readily detected by their brightgreen fluorescence, asymmetry and size in whole homogenates of preputial gland. However, these organelles were absent from the corresponding purified lysosome suspensions, even when the latter represented a concentration 30 or more times that of the whole homogenate. Moreover, when LP2 preparations from the preputial gland were subjected to sucrose-density-gradient analysis the distribution of organelles that fluoresced with Acridine Orange showed a striking coincidence with the localization of acid phosphatase (J. A. Roberts, A. K. Kimura \& B. J. Seeler, unpublished work). The latter enzyme is, by definition, diagnostic of the primary lysosome (Appelmans, Wattiaux \& de Duve, 1955). The DNA content (Burton, 1956) of similar lysosome samples was negligible. In further confirmation of the lack of mitochondrial contamination in purified lysosomes from preputial glands, the values for cytochrome oxidase (cytochrome c-oxygen oxidoreductase, EC 1.9.3.1), measured by the method of Yonetani (1965), were very low (often undetectable) even in suspensions 20 -fold more concentrated than those used for the assay of enzymes of lysosomal origin. For example, the maximal cytochrome oxidase activity observed in a 
WH: Whole homogenate

$(10 \%, w / v)$ in $0.25 \mathrm{M}$-sucrose

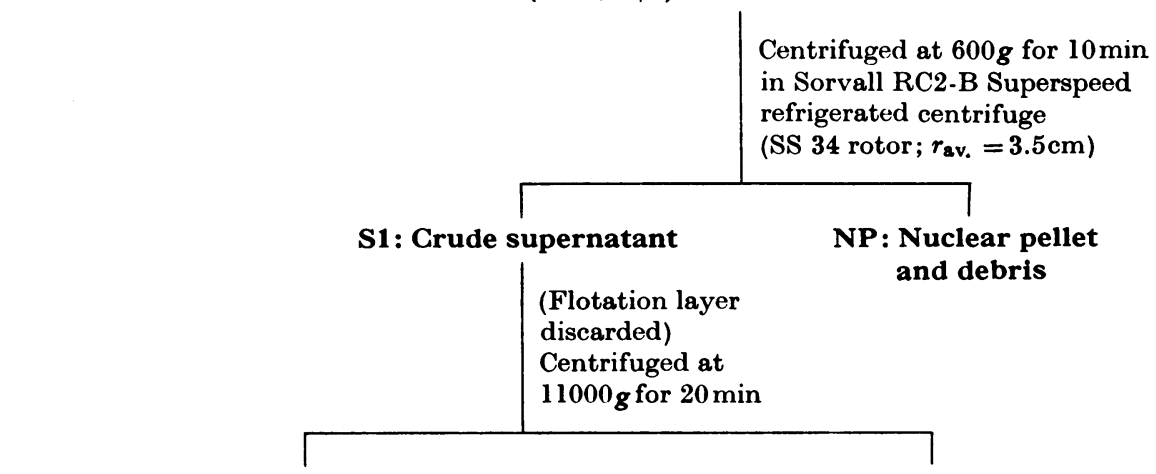

S2: Postlysosomal supernatant

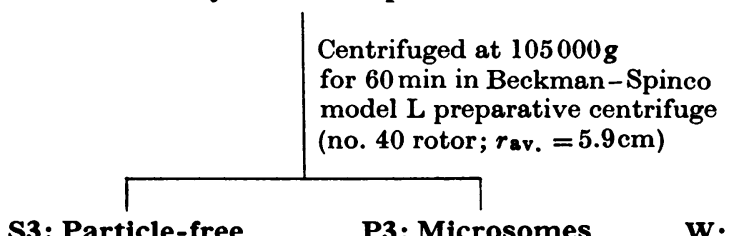

S3: Particle-free supernatant
LP1: Crude lysosomal pellet
Resuspended with Teflon spatula in $0.25 \mathrm{M}$-sucrose $(\sim 8 \mathrm{ml} / 10$ pairs of preputial glands; $\sim 2 \mathrm{ml} / 10$ uteri); centrifuged at $11000 \mathrm{~g}$ for $20 \mathrm{~min}$

\section{LP2: Highly purified} lysosomal pellet

Resuspended in $50 \mathrm{~mm}$-sodium acetate buffer, pH 5.0, in $0.25 \mathrm{M}$-sucrose ( $\sim 20 \mathrm{ml} / 10$ pairs of preputial glands; $\sim 3.5 \mathrm{ml} / 10$ uteri); tested for membrane fragility as described in the text; centrifuged at $105000 \mathrm{~g}$ for $60 \mathrm{~min}$

\section{S4: Supernatant}

R: Residue

Scheme 1. Fractionation of cellular homogenates. All operations were carried out at $0-4^{\circ} \mathrm{C}$. See the text and Fig. 1 for additional details.

representative LP2 preparation of preputial gland was $13-16 \mathrm{nmol}$ of cytochrome $c$ oxidized/min per $\mathrm{mg}$ of protein. This was about $6.5-8 \%$ of the activity generally observed in purified mitochondrial preparations from rat adrenal gland (R. W. McCune, personal communication). The enzyme was absent from high-speed supernatants (S4) of preputial lysosome preparations, even those obtained after $30 \mathrm{~min}$ autolysis (see below). Thus the extraordinarily rich concentration of lysosomes coupled with the relative paucity of mitochondria in the preputial gland, the very converse of the situation that prevails in liver and kidney, favoured the preparation of highly purified organellar fractions that predominated in intact lysosomes and were virtually free of mitochondrial contamination.

Although rat uterus exhibited only $2-6 \%$ of the cytochrome oxidase activity of liver (Woessner, 1965) it is unlikely that the degree of homogeneity seen in the lysosome preparations originating from preputial gland prevailed in those from uterus in the present report. The unique enrichment in lysosomes of the preputial gland has already been noted. Nevertheless the uterine lysosomal preparations yielded results parallel to those obtained in the more comprehensive experiments on preputial-gland samples (see below), suggesting that the hormonal effects to be reported were exerted primarily on the lysosomal elements in both target organs.

Detection of covert labilization of lysosomal membranes. Controlled release of sequestered enzymes from lysosome preparations, or in certain instances from unfractionated homogenates, to the particle-free supernatant was generally achieved by application of either of the following lytic procedures.

(a) Autolysis. The washed lysosome pellet (LP2) was 

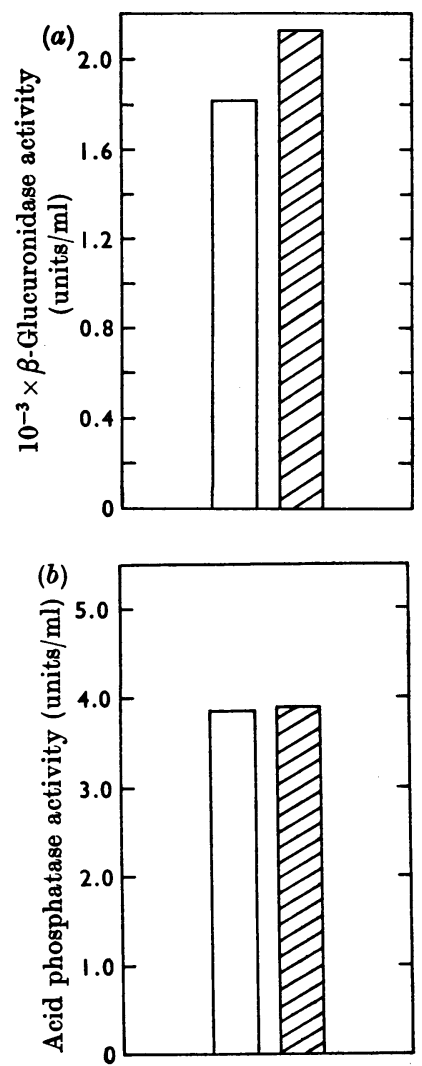
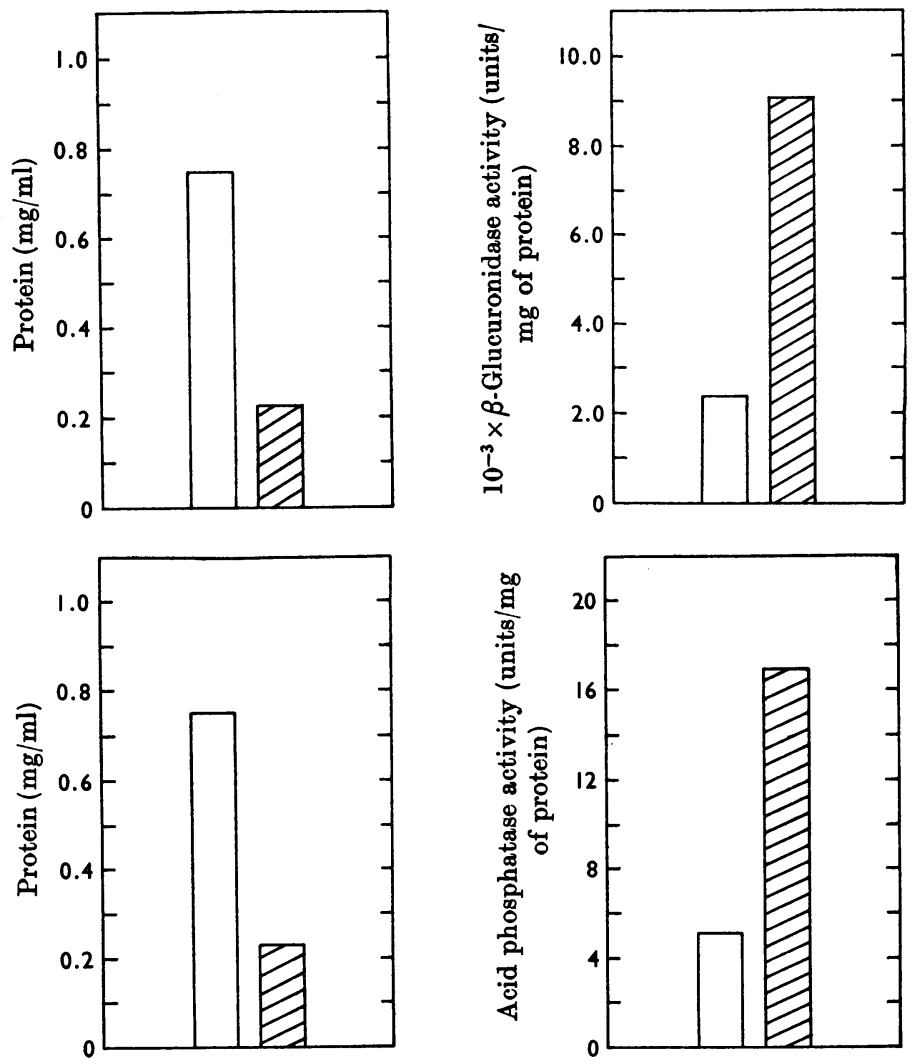

Fig. 1. Influence of method of cell disruption on concentrations of $\beta$-glucuronidase and acid phosphatase in preputial-gland lysosome preparations. Alternate preputial glands from 20 ovariectomized, but otherwise untreated, rats were collected into two pools of essentially equivalent weight. Before homogenization each sample was further prepared as outlined in the text. Thereafter $10 \%(\mathrm{w} / \mathrm{v})$ homogenates in $0.25 \mathrm{M}$-sucrose were prepared, either by the Potter-Elvehjem method ( $\square$ ) or by application of the tissue-press procedure of Emanuel \& Chaikoff (1957) (圆). Purified lysosome fractions (LP2) were then prepared from the homogenates and resuspended as described in Scheme 1. Portions of the preparations were treated with $0.1 \%$ (v/v) Triton $\mathrm{X}-100$, and the resultant $105000 \mathrm{~g}$ supernatants were analysed for $\beta$-glucuronidase $(a)$ and acid phosphatase (b). Protein analysis was carried out on an additional portion of the suspension, solubilized as indicated in the Experimental section. Acid phosphatase was determined with $p$-nitrophenyl phosphate as substrate in sodium citrate buffer, pH4.8, as outlined in the Sigma Chemical Co. Technical Bulletin no. 104 (March 1963; supplement May 1965); 1 unit of activity is defined as $1 \mu \mathrm{mol}$ of $p$-nitrophenol liberated $/ \mathrm{h}$ per ml. Additional details of the analytical methods employed are given in the Experimental section.

carefully resuspended in the appropriate volume of $50 \mathrm{~mm}$ sodium acetate buffer, pH5.0, in $0.25 \mathrm{M}$-sucrose (Scheme 1). For preparations from preputial gland the concentration of particulate material was approx. $0.2 \%(w / v)$. Portions $(2-3 \mathrm{ml})$ were removed to polythene tubes and incubated with gentle shaking (approx. 60 oscillations $/ \mathrm{min}$ ) in a water bath at $37^{\circ} \mathrm{C}$ for various periods.

(b) Detergent. Samples of resuspended lysosome preparations or of unfractionated homogenates were incubated at $37^{\circ} \mathrm{C}$ for $30-45 \mathrm{~min}$ in $50 \mathrm{~mm}$-sodium acetate buffer, pH 5.0, in $0.25 \mathrm{M}$-sucrose, or in $0.25 \mathrm{M}$-sucrose in the presence of $0.1 \%(v / v)$ Triton X-100 (Rohm and Haas Inc., Philadelphia, Pa., U.S.A.). Under these conditions no significant inhibitory effects of the detergent were noted in analyses for enzyme activity subsequently carried out on the resultant supernatants.

After the above procedures the suspension was rapidly chilled and centrifuged for $1 \mathrm{~h}$ at $105000 \mathrm{~g}$ (Scheme 1 ) to yield a particle-free supernatant. Appropriate dilutions of the latter were analysed to detect prior liberation of enzymes from membrane-bound form. The enzyme content of the original suspension and of particulate residues from these procedures was also occasionally measured to ascertain the recovery of enzyme activity.

Determination of enzyme activities. $\beta$-Glucuronidase ( $\beta$-D-glucuronide glucuronohydrolase, EC 3.2.1.31) 
activity was determined at $\mathrm{pH} 4.5$ by the method of Fishman (1963) as modified by Musa, Doe \& Seal (1965), with the substrate phenolphthalein $\beta$-D-monoglucosiduronic acid (Sigma Chemical Co., St Louis, Mo., U.S.A.). In this method 1 Fishman unit represents $1 \mu \mathrm{g}$ of phenolphthalein liberated in $1 \mathrm{~h}$ at $37^{\circ} \mathrm{C}$. Acid phosphatase (orthophosphoric monoester phosphohydrolase, EC 3.1.3. 2) activity was determined in the presence of $0.1 \mathrm{M}$-sodium citrate buffer, pH5.2, by the fluorimetric method of Campbell \& Moss (1961), with $\alpha$-naphthyl phosphate as substrate. The samples were generally incubated for $30 \mathrm{~min}$ instead of the originally specified $15 \mathrm{~min}$ (of. Hirsch, 1968), although linearity of reaction velocity with enzyme concentration was achieved within either time-interval (see below). The $\alpha$-naphthol formed was measured at a fluorescence emission peak of $510 \mathrm{~nm}$ instead of $455 \mathrm{~nm}$.
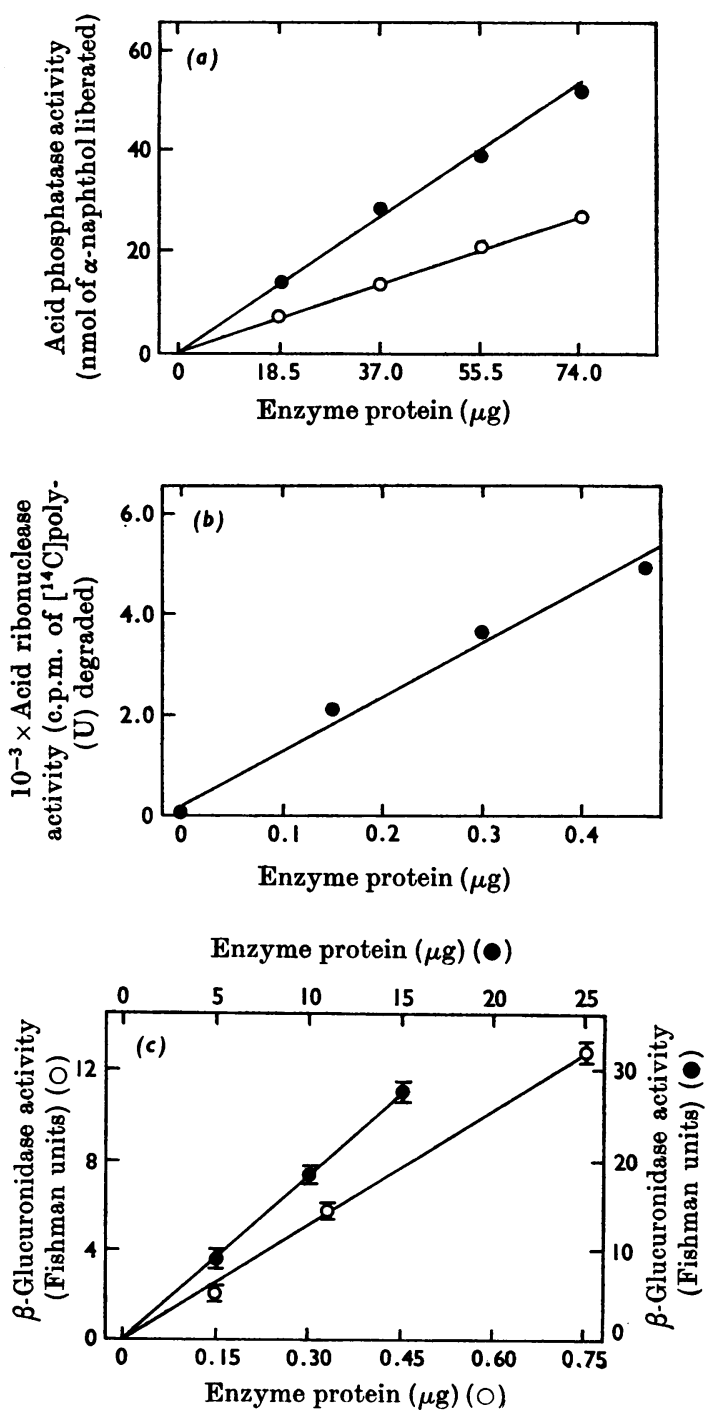

These modifications provided greater sensitivity and specificity of analysis for $\alpha$-naphthol in the presence of undegraded substrate. With the exception of wavelengths for excitation and emission as noted, instrument conditions for fluorimetric analysis were as specified by Szego \& Davis (1969a). In some initial experiments (e.g. Fig. 1) the substrate for acid phosphatase analysis was $p$-nitrophenyl phosphate (cf. Bessey, Lowry \& Brock, 1946), and the reaction was carried out in 0.1 m-sodium citrate buffer, pH 4.8. Assays of acid phosphatase activity were always conducted on the day of experiment to obviate losses on storage of this highly labile enzyme. $\beta$-Glucuronidase, on the other hand, was reliably measured on particle-free supernatants even after storage for up to 2 weeks at $-14^{\circ} \mathrm{C}$. However, determinations of the latter enzyme were carried out within $24 \mathrm{~h}$ of experiment on samples kept at $4^{\circ} \mathrm{C}$. Acid ribonuclease II activity was determined by the method of Barondes \& Nirenberg (1962) as adapted by Zomzely, Roberts, Gruber \& Brown (1968), with the additional modifications specified below. Unless otherwise stated $0.1 \%$ bovine serum albumin (crystallized and freeze-dried; Sigma Chemical Co., St Louis, Mo., U.S.A.) was present in the $1 \mathrm{ml}$ final analytical mixture $(0.14 \mathrm{M}$ sodium acetate buffer, $\mathrm{pH} 5.0$, in the presence of $10 \mathrm{~mm}$ magnesium acetate, $50 \mathrm{mM}-\mathrm{KCl}$ and $10 \mathrm{~mm}$-EDTA). EDTA

Fig. 2. Velocity and enzyme concentration. Enzyme assays were carried out with various concentrations of commercial preparations of acid phosphatase (type II; Sigma Chemical Co.), ribonuclease (Hirs component A, chromatographically homogeneous and salt- and proteasefree; Calbiochem, Los Angeles, Calif., U.S.A.) and $\beta$ glucuronidase (Ketodase; Warner-Chilcott Laboratories, Morris Plains, N.J., U.S.A.) by procedures specified in the text, Table 1 and below. Serial dilutions of standard enzyme were analysed for acid phosphatase activity (a) by the method of Campbell \& Moss (1961), with the excitation and emission wavelengths originally specified. Incubation of duplicate samples was carried out for $15(0)$ or 30 (๑) $\mathrm{min}$, with analytical values that agreed within $1.4 \%$. Ordinate values are based on the standard fluorimetric concentration curve of the $\alpha$-naphthol product. Ribonuclease activity (b) was assayed at the various concentrations of standard enzyme indicated, in a final volume of $1 \mathrm{ml}$, as described in the text. The reaction mixture contained $10 \mathrm{~mm}$-EDTA, as specified, to simulate more closely the conditions utilized for determination of acid ribonuclease of lysosomal origin in the unknown samples (see below). Each point shown is the mean of duplicate $30 \mathrm{~min}$ incubation samples, which varied within $<1 \%$. For $\beta$-glucuronidase (c) analyses of multiple concentrations of appropriately diluted standard enzyme (•) or of those of a typical particle-free supernatant arising from $2 \mathrm{~h}$ autolysis of preputial-gland lysosomes (S4 in Scheme 1) (O) are represented. Each point represents the mean and its standard error of determinations from five individual samples, each analysed in duplicate, with agreement between the latter within $2.5 \%$. Enzyme protein concentrations shown were determined by the method of Lowry et al. (1951) as described in the text, except that solubilization was achieved without recourse to detergent. 

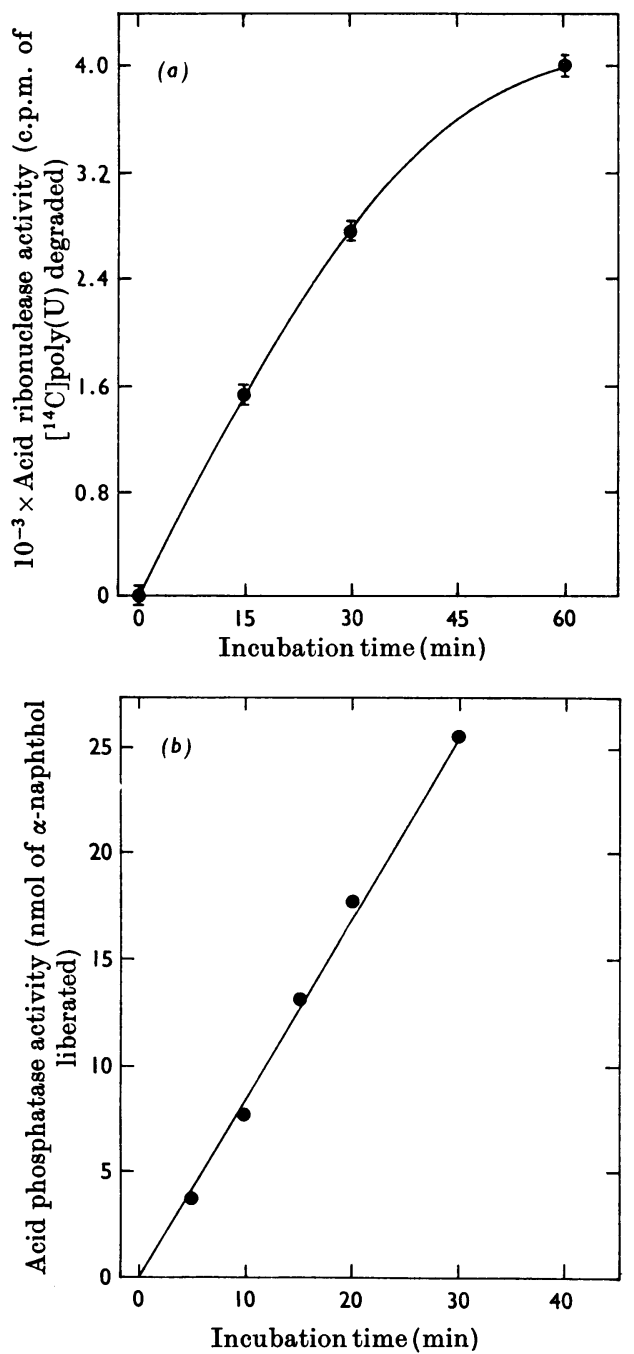

Fig. 3. Time-course of enzyme reaction: (a) ribonuclease; (b) acid phosphatase. The commercial preparations of ribonuclease and acid phosphatase utilized in Fig. 2 were analysed under conditions similar to those described in that figure, except for the omission of bovine serum albumin and EDTA from the ribonuclease assay, and with fixed concentrations of each enzyme used throughout. For ribonuclease $(a)$ this constituted $0.3 \mu \mathrm{g}$ of protein ( $11 \times 10^{-2}$ Kunitz units) (Calbiochem) present in the assay tube. For acid phosphatase $(b) 50 \mu \mathrm{g}$ of enzyme ( $\bumpeq 37 \mu$ g of protein) was the corresponding value. Results in $(a)$ represent the means and s.E.M. of four separate series of analyses, each of which in turn was carried out at the four time-points indicated, with a mean agreement of $1.8 \%$ between duplicates. In $(b)$ the results shown are means of duplicate analyses, which agreed within $2.3 \%$.

was utilized to discriminate in favour of the reactivity of acid ribonuclease II, of lysosomal origin, which as the present investigations confirm is inhibited by $\mathrm{Mg}^{2+}$
(Razzell, 1967; Barnard, 1969). The reaction was started by the addition of $0.1 \mathrm{ml}$ of the substrate, potassium $\left[{ }^{14} \mathrm{C}\right]$ polyuridylate (approx. 8880 d.p.m.) (Schwarz BioResearch Inc., Orangeburg, N.Y., U.S.A), with a resultant final concentration of $50 \mu \mathrm{M}$ as polynucleotide $P$. Incubation was carried out at $37^{\circ} \mathrm{C}$, with occasional agitation; $0.2 \mathrm{ml}$ portions were removed from duplicate tubes at intervals of 0-60 min for precipitation of undegraded $\operatorname{poly}(U)$, which was collected and washed on Millipore filters as described by Zomzely et al. (1968). The air-dried filters were then placed in scintillation-counting vials, to each of which was added $5 \mathrm{ml}$ of a medium containing $0.4 \%$ 2,5-diphenyloxazole and $0.01 \%$ 1,4-bis-(5-phenyloxazol-2-yl)benzene in spectral-grade toluene (Matheson, Coleman and Bell Inc., East Rutherford, N.J., U.S.A.), and analysed for radioactivity in a Packard Tri-Carb (model 314-EX2) spectrometer. Portions of the assay medium, in the absence of enzyme, were treated in the same manner. Counting efficiency was approx. 63.5\%. Recovery of added radioactivity exceeded $99 \%$. Corrections for quenching were not required. It was established by means of this procedure that the sucrose used in the preparation of tissue samples was ribonuclease-free.

Determinations of lysosomal enzyme activity were generally carried out in duplicate, in parallel with simultaneous analyses of standards at three or more points. Analytical values of replicates agreed closely (Figs. 2 and 3; see also Table 1). Fig. 2 also demonstrates the linearity of velocity with enzyme concentration for commercial preparations of corresponding function. A similar degree of analytical reliability prevailed when serial dilutions of experimental unknown were analysed, as shown for $\beta$-glucuronidase in Fig. 2. Moreover, when known concentrations of commercial preparations of $\beta$-glucuronidase, acid phosphatase or ribonuclease were incubated for $30-60 \mathrm{~min}$ at $37^{\circ} \mathrm{C}$ with various concentrations of particlefree supernatants, obtained from preputial-gland lysosomal suspensions that had been subjected to prolonged autolysis, the enzyme activities recovered were additive within approx. $5 \%$ of the theoretical value. Known concentrations of standard enzymes incubated with portions of the same supernatants that had been previously boiled exhibited only the enzyme activity attributable to the commercial products. Fig. 3 demonstrates the kinetics of the assays for ribonuclease and acid phosphatase with commercial preparations of these enzymes. The timecourses for these assays at $37^{\circ} \mathrm{C}$ were linear over $30 \mathrm{~min}$ under the conditions of enzyme and substrate concentrations specified.

Determination of protein. This was carried out by the method of Lowry, Rosebrough, Farr \& Randall (1951) on suitable portions of the fractions indicated. Where required, exposure to $0.1 \%(\mathrm{v} / \mathrm{v})$ Triton $\mathrm{X}-100$ in the presence of $0.1 \mathrm{M}-\mathrm{NaOH}$ for $30 \mathrm{~min}$ at $37^{\circ} \mathrm{C}$ was used to effect prior solubilization of particulate material. Dry purified bovine serum albumin (Sigma Chemical Co.) served as standard.

\section{RESULTS}

Effects of oestrogen on structural latency of lysosomal enzymes in the preputial gland. Highly purified lysosome preparations originating from the preputial glands of rats pretreated for the intervals 
Table 1. Reproducibility of the labilizing influence of oestrogen in vivo on structural latency of lysosomal hydrolases of rat preputial glands

Ovariectomized rats were prepared as described in the text. Diethylstilboestrol $(1 \mu \mathrm{g} / 100 \mathrm{~g}$ body wt.) or saline control solution was administered intravenously $15 \mathrm{~min}$ before removal of preputial glands under Nembutal anaesthesia. Cellular disruption of the minced organs, as a $10 \%(\mathrm{w} / \mathrm{v})$ suspension in $0.25 \mathrm{M}$-sucrose, and preparation of highly purified lysosome fractions were carried out by methods described in the text, Scheme 1 and Fig. 1. Where indicated, quadruplicate portions of the resuspended lysosomal pellets (LP2 in Scheme 1) were subjected to autolysis or to brief treatment with Triton X-100 as described in the text. Enzyme analyses were conducted in duplicate on the resultant $105000 \mathrm{~g}$ supernatants (S4 in Scheme 1). Dilutions of supernatant samples suitable for enzyme analysis were prepared in the presence of $0.1 \%$ bovine serum albumin. Analyses for particulate protein, with a mean variation of less than $2 \%$ between duplicates, were carried out independently on each portion of the solubilized original LP2 suspension. With the exceptions noted, analytical procedures were as described in the Experimental section and in legends to Figs. 2 and 3, wherein is also indicated the degree of variability of duplicate determinations for the several enzymes. Specific activity is defined as the ratio of enzyme activity present in the particle-free supernatant to the weight of total protein in equivalent volume of suspension. For $\beta$-glucuronidase these values are expressed as Fishman units $/ \mu \mathrm{g}$ of protein. The corresponding activity of acid phosphatase is expressed as nmol of $\alpha$-naphthol liberated/30 min per $\mu \mathrm{g}$ of protein; that for acid ribonuclease II is given as $10^{-3} \times$ c.p.m. of $\left[{ }^{14} \mathrm{C}\right]$ poly $(\mathrm{U}) \operatorname{degraded} / 15 \mathrm{~min}$ per $\mathrm{mg}$ of protein. The results are shown as means \pm S.E.M. Initial values are for otherwise untreated control samples representative of the autolysed or detergent-treated preparations.

\begin{tabular}{|c|c|c|c|c|c|c|c|c|c|}
\hline & & & & Sp. & activity & & & & \\
\hline Group & Initial & $t$ & $P^{*}$ & $\begin{array}{l}60 \mathrm{~min} \\
\text { autolysis }\end{array}$ & $t$ & $P^{*}$ & $\begin{array}{l}\text { Triton } \\
\text { X-100 }\end{array}$ & $t$ & $P^{*}$ \\
\hline$\beta$-Glucuronidase & & & & & & & & & \\
\hline Control & $1.33 \pm 0.02$ & 2.96 & 0.02 & $3.85 \pm 0.05$ & 13.28 & $<0.001$ & $4.27 \pm 0.43$ & 4.23 & $<0.01$ \\
\hline $\begin{array}{l}\text { Diethyl- } \\
\text { stilboestrol }\end{array}$ & $1.54 \pm 0.07$ & & & $5.22 \pm 0.09$ & & & $6.14 \pm 0.10$ & & \\
\hline Acid phosphatase & & & & & & & & & \\
\hline Control & $0.22 \pm 0.01$ & 1.18 & n.s. & $0.97 \pm 0.07$ & 3.47 & $<0.02$ & $2.72 \pm 0.16$ & 3.93 & $<0.01$ \\
\hline $\begin{array}{l}\text { Diethyl- } \\
\text { stilboestrol }\end{array}$ & $0.19 \pm 0.01$ & & & $1.33 \pm 0.08$ & & & $3.63 \pm 0.17$ & & \\
\hline Acid ribonuclease & & & & & & & & & \\
\hline Control & $15.76 \pm 0.05$ & 6.28 & $<0.001$ & $60.01 \pm 0.07$ & 82.03 & $<0.001$ & $122.12 \pm 0.06$ & 80.17 & $<0.001$ \\
\hline Diethyl- & $16.30 \pm 0.07$ & & & $72.45 \pm 0.13$ & & & $161.39 \pm 0.50$ & & \\
\hline
\end{tabular}

* Probability of significant difference between the diethylstilboestrol and control groups calculated by the StudentFisher $t$ test.

indicated with oestrogen or saline control solution were obtained by fractionation as depicted in Scheme 1. These were subjected to controlled autolysis by incubation in buffered acidic sucrose at $37^{\circ} \mathrm{C}$ or treated with the detergent Triton X-100 as described above to detect covert labilization of the lysosomal membrane. Diethylstilboestrol, administered intravenously ( $1 \mu \mathrm{g} / 100 \mathrm{~g}$ body wt.) $15 \mathrm{~min}$ before sample collection, produced a striking increase in the sensitivity of the lysosomal surface to these procedures. In the experiment depicted in Table 1 augmented liberation of lysosomal enzymes was evident by two of the three enzymatic criteria even in the initial samples, which were centrifuged promptly in the cold and thus served as autolysis controls. The progress of autolysis during incuba- tion for $60 \mathrm{~min}$ at $37^{\circ} \mathrm{C}$ was likewise accelerated in the samples originating from the oestrogen-pretreated group. Similarly an accentuated degree of lysosome-membrane labilization, as revealed by augmented release of $\beta$-glucuronidase, acid phosphatase and acid ribonuclease to the particle-free supernatant by challenge with detergent also reflected prior exposure to oestrogen in vivo. These effects of oestrogen pretreatment were reproducible to a high degree of statistical significance. Thus the phenomenon was observed repeatedly in a series of experiments, comparable with the one depicted in Table 1 , in which $\beta$-glucuronidase was measured (Table 2). Because of the variability of control base-lines, a property inherent in the particulate nature of the system under investigation, statistical 
Table 2. Labilizing influence of oestrogen in vivo on structural latency of lysosomal $\beta$-glucuronidase of rat preputial glands

Experimental procedures were as described in Table 1, except that the results shown represent means \pm S.E.M. for the numbers of separate experiments shown in parentheses.

Sp. activity of $\beta$-glucuronidase

(Fishman units/ $\mu \mathrm{g}$ of particulate protein)

Lytic procedure

Autolysis series

Incubation time (min)

$\begin{array}{rlr}0 & 1.10 \pm 0.14(11) \\ 30 & 2.71 \pm 0.19(9) \\ 240 & 4.15 \pm 0.36\end{array}$

Control Diethylstilboestrol

$$
\begin{array}{cc}
P^{*} & P \dagger \\
& \\
0.3 \text { (n.s.) } & >0.05 ;<0.1 \text { (n.s.) } \\
>0.01 ;<0.02 & 0.001 \\
>0.01 ;<0.02 & >0.01 ;<0.02 \\
>0.001 ;<0.01 & <0.001
\end{array}
$$$$
4.01 \pm 0.41 \quad(9)
$$$$
6.42 \pm 0.73(7)
$$

* Probability of significant difference from the control group calculated by the Student-Fisher $t$-test (n.s., not significant).

$\dagger$ Probability of significant difference from the corresponding control within each experiment calculated by the paired $t$ test (Moroney, 1957) (n.s., not significant).

significance of the oestrogen-sensitizing influence was especially striking when analysed on the basis of direct, intra-experiment, paired controls (Table 2). Moreover, the differences in lysosomal membrane lability to autolysis between oestrogen- and saline control solution-pretreated groups were statistically significant up to $4 \mathrm{~h}$ of incubation. Invariably oestrogen pretreatment was also reflected in increased sensitivity of purified lysosome preparations to the enzyme-stripping effects of Triton X-100. The values observed for $\beta$-glucuronidase liberation after exposure to this detergent were often comparable with those resulting from $4 \mathrm{~h}$ autolysis (Table 2 ).

Release of lysosomal enzymes by autolysis or by brief treatment with $0.1 \%$ Triton $\mathrm{X}-100$ was submaximal, as revealed by the appreciable enzyme activity remaining in the particulate residues (see below). Higher concentrations of Triton X-100 were avoided because of the possibility of inhibitory effects on the enzymes liberated to the particle-free supernatant. Exposure of the lysosomal preparations to $0.1 \%$ Triton $\mathrm{X}-100$ for longer periods than usual (up to $2 \mathrm{~h}$ at $37^{\circ} \mathrm{C}$ ) yielded virtually equivalent enzyme concentrations in the particle-free supernatants from control and oestrogen-pretreated groups. These values were invariably higher than those resulting from exposure to any other form of challenge to lysosomal integrity in vitro, including sonication, freezing and thawing and hypo-osmoticity (not shown), and appeared to be nearmaximal. For example, when portions of a preputial-gland lysosome preparation from a set of animals pretreated with saline control solution were exposed in vitro to $0.1 \%$ Triton X-100 for $45 \mathrm{~min}$ and for $2 \mathrm{~h}$, the specific activities of $\beta$-glucuronidase in the particle-free supernatants were 5.23 and 7.68 Fishman units/ $\mu \mathrm{g}$ of particulate protein respectively. The samples from a group of animals concomitantly treated for $15 \mathrm{~min}$ in vivo with diethylstilboestrol $(1 \mu \mathrm{g} / 100 \mathrm{~g}$ body wt.) exhibited corresponding mean activities of 8.01 and 8.01 Fishman units $/ \mu \mathrm{g}$. When residual enzyme activities in the correlative particulate fractions of the samples from control and diethylstilboestroltreated animals exposed to the detergent for $2 \mathrm{~h}$ were taken into account, the total specific activities were essentially equivalent: 8.28 and 8.32 Fishman units/ $\mu$ g of protein respectively. In turn the total values so obtained were equal to those resulting from direct analysis of the corresponding uncentrifuged suspensions exposed to detergent for $45 \mathrm{~min}$ or $2 \mathrm{~h}$ (8.29 and 8.46 Fishman units/ $\mu \mathrm{g}$ of protein). Parallel observations were made for acid phosphatase and acid ribonuclease II. Since the total enzyme yields from otherwise equivalent control and experimental samples were thus comparable, it may be concluded that brief exposure to Triton X-100 (Tables 1 and 2) solubilized a higher proportion of total lysosomal enzyme in the samples originating from oestrogen-pretreated groups than in the paired controls.

The surface membranes of lysosomes from various organs are not equally susceptible to disruption (cf. Weissman, Hirschhorn, Pras, Sessa \& Bevans, 1967). In this respect preputial-gland lysosome preparations are thus clearly unlike those of liver, for example, which are highly vulnerable to detergent labilization (cf. de Duve, Wattiaux \& Wibo, 1962). Possibly the difference in gross stability is the reflexion of membrane composition : in preputialgland samples inordinately high concentrations 
Table 3. Lack of influence of oestrogen in vivo on total $\beta$-glucuronidase or on its detergent-induced solubilization in unfractionated homogenates of rat preputial glands

Preputial-gland homogenates were prepared from ovariectomized rats treated as described in Table 1. Portions of the well-suspended samples were subjected to treatment with Triton X-100 as described in the text. $\beta$-Glucuronidase activity was determined directly on a suitably diluted portion of the mixture, and also on the supernatant and residual fractions resulting from its centrifugation at $105000 \mathrm{~g}$. The values for total activities by direct analysis and by summation agreed within $3 \%$. Analyses for total protein were carried out on another portion of the suspension, solubilized as indicated in the text. Analytical procedures and units of enzyme activity were as described in the Experimental section and in Table 1. The results are given as means \pm S.E.M. of the numbers of individual experiments shown in parentheses.

Sp. activity (Fishman units/ $\mu$ g of protein)

\begin{tabular}{|c|c|c|c|c|c|c|}
\hline \multirow[b]{2}{*}{ Group } & & & & & & \\
\hline & Supernatant & $t$ & $P^{*}$ & Total & $t$ & $P^{*}$ \\
\hline Control & $9.90 \pm 0.49(6)$ & & & $11.77 \pm 0.44(7)$ & & \\
\hline Oestrogen-treated & $9.98 \pm 0.76(8)$ & 0.082 & n.s. & $11.52 \pm 0.63(9)$ & 0.308 & n.s. \\
\hline
\end{tabular}

and a complex mixture of sterols are present (cf. Kandutsch \& Russell, 1960), only a portion of which are removed from the crude supernatant as part of a gross flotation layer.

Selectivity of the effect of oestrogen on labilization of the lysosomal membrane. Additional findings supported the conclusion that the enhancement by oestrogen of the release of acid hydrolases from characteristically bound form in the primary lysosomal population was attributable to covert membrane damage specific to these organelles. In contrast with the sensitivity of lysosomal binding sites for $\beta$-glucuronidase to prior exposure to oestrogen, the relative proportions of this enzyme solubilized by Triton X-100 from crude unfractionated homogenates of preputial gland were independent of hormonal treatment (Table 3). Fishman, Goldman \& DeLellis (1967) have indicated that binding sites for $\beta$-glucuronidase other than the lysosomal ones abound in this organ, and possess labilization properties distinct from those of the latter. The present results support this conclusion. The results in Table 3 further suggest that the increased amounts of $\beta$-glucuronidase solubilized by brief exposure to Triton X-100 from highly purified lysosome fractions of the preputial gland as a consequence of oestrogen pretreatment (Tables 1 and 2) were not attributable to differences in enzyme content inherent in the corresponding initial homogenates.

Although $\beta$-glucuronidase occurred in other subcellular fractions of the preputial gland, this enzyme served as a highly specific indicator of the oestrogen-induced decrease in lysosomal membrane stability in this hormonal target tissue. Thus oestrogen-augmented rates of liberation of preputialgland $\beta$-glucuronidase and acid phosphatase from particle-bound form during autolysis were pro- portional over a wide range of enzyme concentrations, with a highly significant correlation coefficient of 0.983 (Fig. 4). Subcellular localization of the latter enzyme is highly specific to the intact lysosome (Appelmans et al. 1955). These data, taken together with the results in Table 1 and 2, strongly suggest that the two enzymes, whose accentuated liberation from binding was provoked by oestrogen, have a common cytostructural origin. These observations were further paralleled by results on oestrogen-enhanced release of an acid ribonuclease from particulate-bound form in preputial-gland lysosome preparations (Fig. $5 a$; see also Table 1, and Fig. 6 below). This enzyme exhibited a number of properties in both preputialgland and uterine lysosome fractions that were characteristic of acid ribonuclease II, including lack of dependence on $\mathrm{Mg}^{2+}$ (indeed, depression of activity in the presence of this ion), acid $\mathrm{pH}$ optimum, freedom from inhibition by endogenous substances in crude preparations and inertness towards poly(A) as substrate (Razzell, 1967; Barnard, 1969). Acid ribonuclease II, in common with acid phosphatase, appears to be strictly of lysosomal origin (Barnard, 1969). The diminished structural latency thus evidenced in parallel by three lysosomal 'marker' enzymes in highly purified lysosome fractions prepared from preputial gland after oestrogen administration in vivo was strongly suggestive of a common underlying mechanism for lytic activation.

Organ selectivity. Previous studies had demonstrated that the liberation of $\beta$-glucuronidase to the particle-free supernatant prepared from rat uterus (comparable with fraction S3 in Scheme 1) was augmented after oestrogen pretreatment in vivo (cf. Szego \& Davis, 1969b). The present investigations support the indication that exposure to 


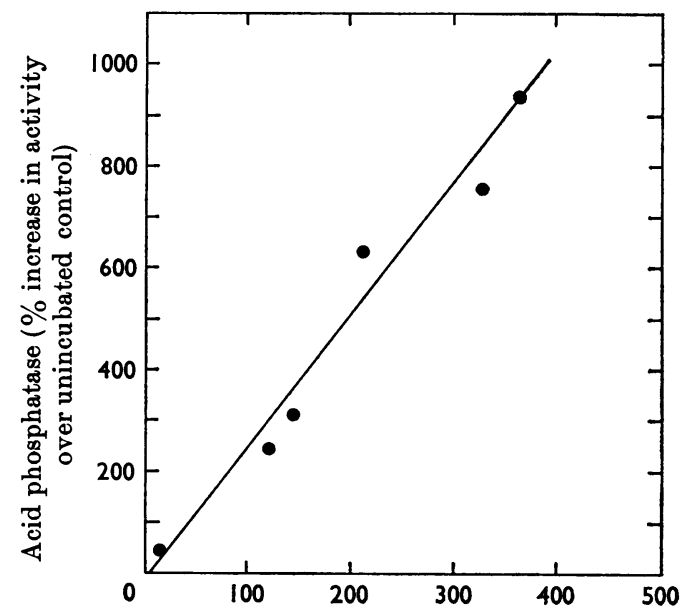

$\beta$-Glucuronidase ( $\%$ increase in activity over unincubated control)

Fig. 4. Aggravation of lytic susceptibility of lysosome preparations by pretreatment with oestrogen : correlation between augmented release of acid phosphatase and $\beta$-glucuronidase to the particle-free medium during progressive autolysis. Experimental procedures were as described in Table 1 , except that the oestrogen was oestradiol-17 $\beta(1 \mu \mathrm{g} / 100 \mathrm{~g}$ body wt.). The results originated from duplicate determinations of the enzyme activities indicated in the S4 supernatants of preputialgland lysosome preparations from saline control solutionand oestrogen-pretreated groups. Sampling of the suspensions under the conditions of autolysis described in the text was carried out at $0,10,20,30,60$ and $120 \mathrm{~min}$ of incubation. The values shown represent the mean percentage increases of the relevant enzyme activities in samples from the oestrogen-treated series compared with the corresponding values in initial (unincubated) control samples. The specific activities of the latter were 1.13 Fishman units $/ \mu \mathrm{g}$ of protein, and $0.11 \mathrm{nmol}$ of $\alpha$-naphthol liberated $/ 30$ min per $\mu$ g of protein for $\beta$-glucuronidase and acid phosphatase respectively. The equation of the line drawn was calculated by the method of least squares (Moroney, 1957). The resultant correlation coefficient between the two sets of observations was 0.983 .

oestrogen diminishes lysosomal integrity in this target organ as well as in the preputial gland, which is much richer in lysosomes. Thus prior treatment with diethylstilboestrol in vivo enhanced the release of acid ribonuclease II from particle-bound form in lysosome-enriched preparations from uterus subjected to autolytic conditions (Fig. 5b). Comparable results were obtained when the natural oestrogen, oestradiol-17 $\beta$, was substituted for diethylstilboestrol (Table 4). Covert lytic activation attributable to oestrogen pretreatment, as judged by sensitivity to detergent, was also noted in the latter experiments. In contrast with the

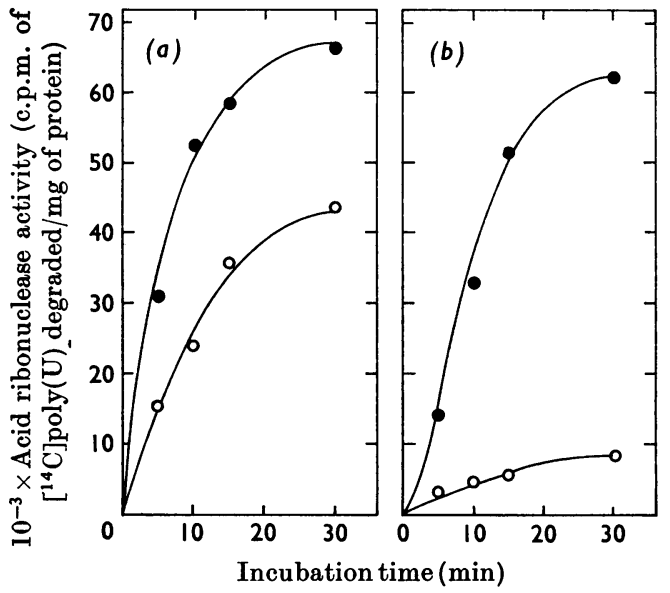

Fig. 5. Influence of oestrogen pretreatment on autolytic susceptibility of lysosome preparations: accentuated release of acid ribonuclease II to the particle-free medium. Experimental procedures were as described in Table 1, Fig. 2 and the text. (a) Analyses for acid ribonuclease II carried out on the $105000 \mathrm{~g}$ supernatants (S4) of purified preputial-gland lysosome preparations (LP2) that had been subjected to autolysis for $60 \mathrm{~min}$; $(b)$ results for the corresponding lysosome-enriched samples of uterus exposed to autolytic conditions for $2 \mathrm{~h}$. The preparations originated from ovariectomized rats injected intravenously $15 \mathrm{~min}$ before organ removal with saline control solution (O) or diethylstilboestrol $(1 \mu \mathrm{g} / 100 \mathrm{~g}$ body wt.) (•). Values indicated on the abscissa represent time of sampling of the enzyme assay-tubes (cf. Fig. 3). These results are representative of a series of three experiments carried out at intervals over a 3 -month period.

results with uterine and preputial-gland preparations, the lytic susceptibility of lysosome-enriched fractions of rat lung and kidney was independent of pretreatment with gonadal hormone (Szego, 1971a).

Hormone specificity. The results indicate that oestradiol-17 $\beta$ shares the capacity of diethylstilboestrol to provoke lysosome-membrane instability. In contrast, the unnatural epimer, oestradiol-17 $\alpha$, failed to aggravate uterine lysosome-membrane instability by the present criteria, notwithstanding its administration in doses 25 times those of its oestrogenically active $\beta$-analogue (Table 4). Oestradiol-17 $\alpha$ was also ineffective in provoking acute elevation of cyclic AMP concentration in rat uterus (Szego \& Davis, 1967). The inactivity of oestradiol$17 \alpha$ as a lysosome-membrane labilizer was also observed in preputial-gland preparations exposed to Triton X-100 (Table 5).

Lytic susceptibility of preputial-gland lysosome preparations was aggravated by prior administration of testosterone (Table 6). Testosterone is a more generally recognized trophic hormone for the 
Table 4. Stereochemical specificity of the effect of oestradiol in decreasing the structural latency of acid ribonuclease II of lysosome-enriched preparations of uterus

With the exceptions noted, experimental and analytical procedures were as described in Table 1. Time of incubation in the ribonuclease assay was $10 \mathrm{~min}$, except for the autolysis samples in the first experiment, in which it was $5 \mathrm{~min}$. The values for specific activity were individual observations. Results are shown for three experiments consisting of control animals treated as described in the text and Table 1, and ovariectomized rats given either oestradiol-17 $\alpha(2.5 \mu \mathrm{g} / 100 \mathrm{~g}$ body wt. $)$ or oestradiol-17 $\beta(0.1 \mu \mathrm{g} / 100 \mathrm{~g}$ body wt. $)$ intravenously $15 \mathrm{~min}$ before organ sampling. Specific activity is defined as $10^{-3} \times$ c.p.m. of $\left[{ }^{14} \mathrm{C}\right] \mathrm{poly}(\mathrm{U}) \mathrm{degraded} / 15 \mathrm{~min}$ per $\mathrm{mg}$ of protein.

Sp. activity

\section{Group}

Control

Oestradiol-17 $\alpha$

Oestradiol-17 $\beta$

Control

Oestradiol-17 $\alpha$

Control

Oestradiol-17 $\beta$

$\begin{array}{cc}\begin{array}{c}\text { Autolysis } \\ (60 \mathrm{~min})\end{array} & \begin{array}{c}\% \text { difference } \\ \text { from control }\end{array}\end{array}$

38.55

39.63

26.91

44.67

$+2.8$

$+66.0$

$\begin{array}{cccc}\begin{array}{c}\text { Autolysis } \\ (120 \mathrm{~min})\end{array} & \begin{array}{c}\text { \% difference } \\ \text { from control }\end{array} & \begin{array}{c}\text { Triton X-100 } \\ \text { from difference }\end{array} & \begin{array}{c}\text { \% control } \\ \text { from }\end{array} \\ 27.48 & & 56.60 & \\ 25.40 & -7.6 & 50.24 & -11.2 \\ 43.67 & +58.9 & 88.02 & +55.5\end{array}$

Table 5. Lack of influence of oestradiol-17 $\alpha$ on preputial-gland lysosomal membrane labilization

With the exceptions noted, experimental and analytical procedures were as described in Table 1. The values for specific activity are the means of two replicate samples except where individual observations (1) are indicated; the units are as defined in Table 1. All samples were analysed, as usual, in duplicate. Results are shown for three independent experiments consisting of control animals treated as described in the text and Table 1 , and ovariectomized rats given oestradiol-17 $\alpha(2.5 \mu \mathrm{g} /$ $100 \mathrm{~g}$ body wt.) intravenously $15 \mathrm{~min}$ before organ sampling. In one of the experiments oestradiol-17 $\beta$ was administered in parallel, in the amount of only $0.1 \mu \mathrm{g} /$ $100 \mathrm{~g}$ body wt., under otherwise similar conditions.

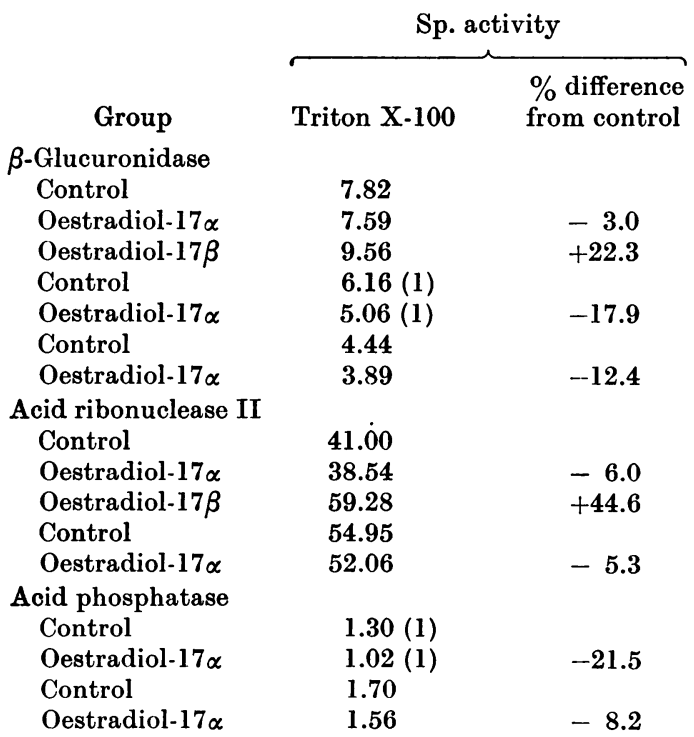

preputial gland (cf. Freinkel, 1963), although responsiveness of this organ to oestrogen has also long been established (Beyler, 1952). On the other hand, testosterone administration did not lead to aggravated lytic instability of lysosome-enriched uterine preparations from ovariectomized rats. Thus the specific activities of acid ribonuclease II liberated to the uterine particle-free supernatants from replicate portions of a control sample that had been subjected to autolytic conditions for $2 \mathrm{~h}$ were $16540,21500,22550$ and 26960 c.p.m. of $\left[{ }^{14} \mathrm{C}\right]-$ poly $(\mathrm{U})$ degraded/mg of particulate protein at 10 , 15,30 and $60 \mathrm{~min}$ of incubation time respectively in the ribonuclease assay. The corresponding values for the preparation from animals receiving $1 \mu \mathrm{g}$ of testosterone $/ 100 \mathrm{~g}$ body wt. intravenously $15 \mathrm{~min}$ before organ excision were $12410,14600,17950$ and 21550 . The lack of influence of testosterone pretreatment on stability of uterine lysosomeenriched preparations was in sharp contrast with the substantial sensitizing effect of this hormone on the preputial-gland samples within the same experimont (Table 6).

Sensitivity. By the present criteria lysosomal membrane integrity was responsive to hormonal doses of a physiological order. Thus the diminished structural latency of acid ribonuclease II during progressive autolysis of purified lysosome fractions prepared from preputial glands of ovariectomized rats treated $15 \mathrm{~min}$ before organ removal was readily demonstrated with doses as low as $0.1 \mu \mathrm{g}$ of oestradiol-17 $\beta / 100$ g body wt. (Fig. 6). Similar results were obtained by using kinetics of $\beta$-glucuronidase or acid phosphatase liberation during autolysis (results not shown) or sensitivity to Triton X-100 (Table 5) as indicators of preputial-gland-membrane 


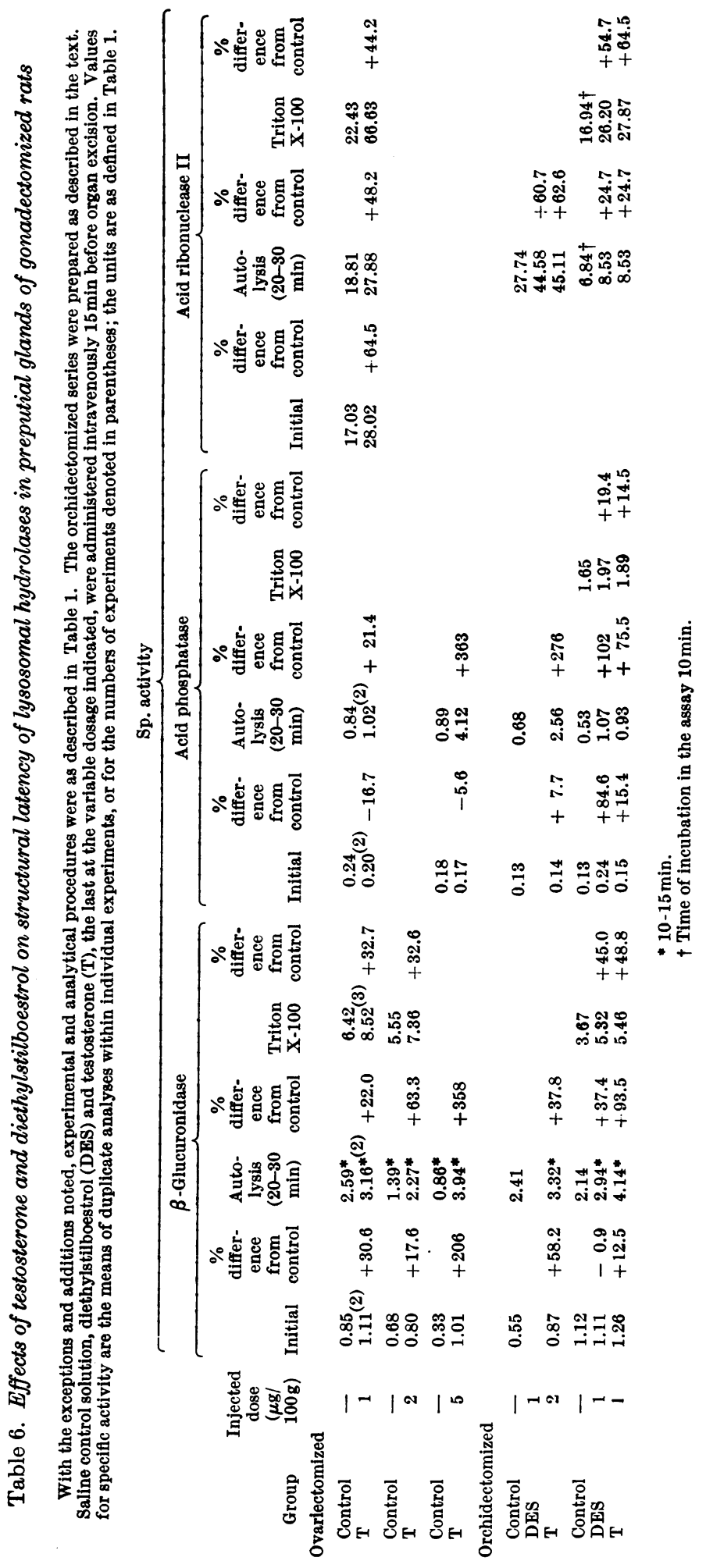




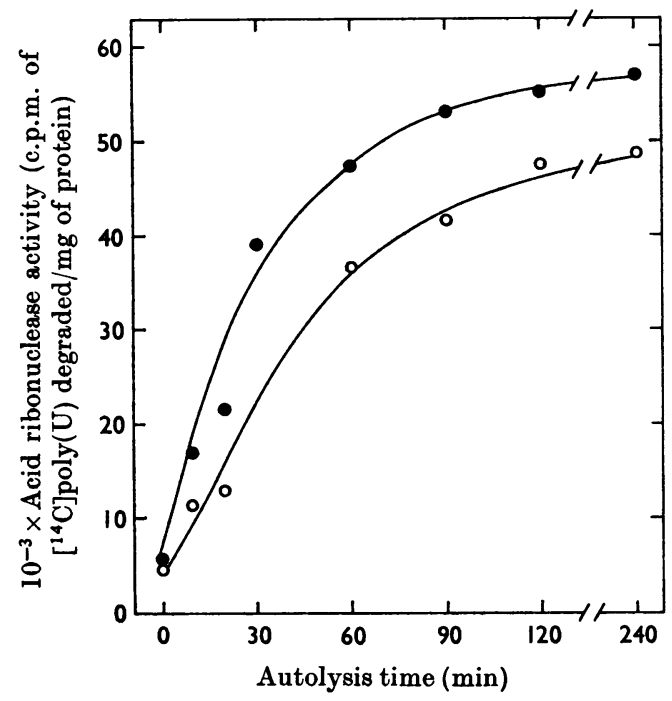

Fig. 6. Aggravation by oestrogen pretreatment of lytic susceptibility of preputial-gland lysosome preparations: augmented release of acid ribonuclease II to the particlefree medium during progressive autolysis. Experimental procedures were as outlined in Figs. 4 and 5, except that the oestrogen (๑) administered was oestradiol-17 $\beta$, in the amount of only $0.1 \mu \mathrm{g} / 100 \mathrm{~g}$ body wt. Sampling of the LP2 suspensions arising from this group or from the corresponding controls $(O)$ was carried out at the autolysis times indicated on the abscissa. The values shown represent analyses for activity of acid ribonuclease II of the resultant S4 supernatant samples that were incubated for $30 \mathrm{~min}$ in the ribonuclease assay procedure. Heightened autolytic susceptibility attributable to pretreatment with the present dose of oestradiol-17 $\beta$ was reproducible in a series of five such experiments carried out at intervals over a 5-month period.

labilization. The responsiveness of lysosomeenriched uterine fractions was of a corresponding order (Table 4), a finding in harmony with the comparable effectiveness of oestradiol-17 $\beta$ in eliciting acute elevation of uterine cyclic AMP concentration in similar animals (Szego \& Davis, 1967).

The lytic response of preputial lysosomes from ovariectomized rats was likewise very sensitive to pretreatment with testosterone (Table 6). An extraordinary degree of lysosome-membrane labilization was provoked by $5 \mu \mathrm{g}$ of this hormone $/ 100 \mathrm{~g}$ body wt., as judged by structural latency of $\beta$-glucuronidase and acid phosphatase. On the criterion of $\beta$-glucuronidase liberation, the lytic influence of this massive dose was seen even in the initial samples, unsubjected to challenge in vitro. The labilizing influence of testosterone was sharply diminished to one that was nevertheless still detectable by the present enzymic indicators after exposure to autolytic conditions or to detergent, when the dose of the androgen was decreased to $1-2 \mu \mathrm{g} / 100 \mathrm{~g}$ body wt. (Table 6). As would be expected, the sensitivity to testosterone of preputialgland lysosome preparations from orchidectomized animals was of a similar order to that seen in corresponding samples from ovariectomized rats (Table 6). Moreover, the labilizing influence of oestrogen, regularly observed in the ovariectomized series, was also evident in the orchidectomized group.

\section{DISCUSSION}

The present findings provide the first detailed evidence that covert labilization of lysosomal membranes of specific targets constitutes an acute, sensitive and site-selective response to steroid hormones and related substances administered in physiological concentrations in vivo (see also Szego, $1970,1971 a$ ). Thus purified lysosome suspensions, essentially free of mitochondria, prepared by mild procedures from homogenates of preputial glands from ovariectomized rats at $15 \mathrm{~min}$ after injection of hormone, demonstrated strikingly diminished structural latency of enzymes characteristic of this organelle to provocative stimuli applied in vitro. These stimuli included exposure to autolytic conditions, detergent and mechanical stress. Covert membrane labilization, occasionally demonstrable even without recourse to these measures, was reflected in concomitantly augmented release from particle-bound form of acid phosphatase, $\beta$ glucuronidase and an acid ribonuclease with properties typical of lysosomal origin. During progressive autolysis there was close correlation of these three enzymes in the increased rates of their liberation to the particle-free supernatant attributable to hormonal intervention. Moreover, the experimental design (which involved rapid chilling and in most cases high-speed centrifugal separation of the membrane-free and particulate phases before enzyme assay, after the application of test proce. dures to detect labilization) precluded hormonal influence on the accessibility of added substrate to enzymes while the latter were still in membranebound state, whether on the inner or the outer aspect of the lysosomal surface (cf. Lloyd, 1969).

The conclusion that pretreatment with oestrogen labilizes lysosomal membranes, leading to liberation of sequestered enzymes, is borne out by the exacerbating effects of prior adrenalectomy on oestrogeninduced augmentation of enzyme release in vitro from preputial-gland lysosome preparations (see Szego, 1971a). These findings would be expected from depletion of the endogenous adrenocortical steroids, whose membrane-stabilizing influence (see Dougherty, 1954 ; de Duve et al. 1962; Weissmann \& 
Thomas, 1963, 1964; Weissmann, 1965a,b) is normally counterpoised to oestrogen action (see Roberts \& Szego, 1953; Szego \& Roberts, 1953; Sziego, 1957; Szego \& Davis, 1969b). In further support of the membrane locus of the present observations is the evidence of finite time required for exposure in vivo to oestrogen for decreased structural latency of lysosomal enzymes to be manifested in vitro by the above criteria. In preliminary experiments it has been observed that, when organ sampling was carried out at only $2 \mathrm{~min}$ after intravenous administration of oestrogen, diminished structural latency of $\beta$-glucuronidase in preputial-gland lysosome preparations of ovariectomized rats was detectable by the brief $(45 \mathrm{~min})$ exposure to Triton X-100. This observation was supported by electron-microscopic evidence of modification in structural latency and subcellular distribution of lysosomal acid phosphatase as a function of pretreatment with oestrogen, even of so short a duration (Smith \& Szego, 1971). Oestrogenic effects of a similarly acute order on intracellular lysosome translocation to perinuclear sites have been noted by fluorescence microscopy (Szego, 1970 ; B. J. Seeler \& C. M. Szego, unpublished work). Ultra-rapid alterations in other membrane-localized functions elicited by oestrogen (Szego \& Davis, $1967,1969 \dot{a}, b$ ) and by cyclic AMP (Griffin \& Szego, 1968; Szego, 1965, 1971 $a$ ) in the uterus show that this organ is likewise acutely responsive to changes in its hormonal environment.

The sensitivity of purified lysosome preparations from the preputial gland of the ovariectomized rat to pretreatment with oestrogen was shared by corresponding fractions from uterus, but not by those from organs, such as lung and kidney, that are essentially unresponsive to this hormone by other criteria (Szego, 1971a). In turn, the increased lytic susceptibility conferred on specific target tissues by oestrogen administration appeared to be confined to that bound fraction of the total enzyme complement sequestered in the lysosomal population. These observations of organ- and organellespecificity are in accord with other indications of the physiological significance of the phenomenon, including the present findings that the membrane surface of lysosomes of selected target tissues is responsive exclusively to those oestrogens possessing demonstrated physiological effectiveness by other criteria in the rat (Szego \& Davis, 1967). Thus the labilizing influence of oestradiol-17 $\beta$ was qualitatively indistinguishable from that of diethylstilboestrol, whereas oestradiol-17 $\alpha$, in a dose 25 times that effective for its oestrogenically active $\beta$-epimer, was essentially inert; both in preputial gland and uterus. Preputial-gland lysosome stability was unaffected by prior intravenous administration of cholesterol in the amount of $1 \mu \mathrm{g} / 100 \mathrm{~g}$ body wt.
(Szego, 1971a). In the present investigation the autolytic sensitivity of lysosome-enriched preparations of uterus was inert to testosterone given in equivalent dose by the same route. The relative independence of uterus from androgenic control is well established. In harmony with the known effectiveness of testosterone as a trophic hormone for the preputial gland, on the other hand, this steroid was capable of evoking membrane instability in lysosome-rich preparations of this organ from gonadectomized animals of either sex. This effect was evident at doses in vivo to which no acute target response has heretofore been detected by any other criterion, and in roughly a concentration-dependent manner. Diethylstilboestrol has a similar order of effectiveness in the preparation from orchidectomized animals.

The present investigation has provided direct evidence that acute modifications in lysosomal function, in all likelihood secondary to alterations in structure as a consequence of site-selective protein interaction with specific gonadal hormones and diethylstilboestrol in vivo, occur in established targets. By contrast, previous association of lysosomal function with steroid hormones has been limited for the most part to recognition of detergent effects of these and related compounds, added in vitro in supra-pharmacological concentrations, on the integrity of lysosomes from various tissues (de Duve et al. 1962; Scheib, 1963; Weissmann, $1965 a, b)$. Participation of these organelles in sustained secretory activity or in regressive patterns of tissue function during involutional phenomena in sex hormone targets has also received attention (cf. Woessner, 1969). There are, moreover, well-documented reports of increases in lysosome production (Smith \& Henzl, 1969) and induction in specific target tissues of certain enzymes (cf. Fishman \& Fishman, 1944), now recognized to be concentrated in lysosomes, by prolonged administration of sex hormones at high doses. However, the present results are the first to demonstrate acute effects of hormonally active substances, administered in vivo in doses of a physiological order, on the stability of lysosomal membranes of specific targets.

There is now a voluminous literature demonstrating the likelihood of lysosomal participation in the normal cellular economy as well as in pathological processes (cf. de Duve \& Wattiaux, 1966; Dingle \& Fell, 1969). Moreover, there is growing acceptance of the concept that the character and integrity of the bounding membrane suffers modification on interaction with a variety of physical and chemical stimuli of extracellular origin (Duncan, 1966; Allison, 1968), thereby determining the susceptibility of the sequestered hydrolytic enzymes to graded escape. The primary lysosomal popula- 
tion of target cells has additional properties that are uniquely adapted to the interception of extracellular biocatalytic signals and their efficient amplification by processes poised for triggering with minimum input (Allison, 1968; Fell, 1969; Szego, $1971 a)$.

Lytic activation of the lysosomal surface by gonadal hormones may bear special significance for propagation of the manifold secondary responses of target tissues to these agents. Thus liberation of a battery of degradative enzymes, of which the three investigated in the present work are representative, may provide the means for such an attack on existing macromolecular constituents of the target as may underlie the phenomena of matricular depolymerization (cf. Catchpole, 1966), inflammation (cf. Billing, Barbiroli \& Smellie, 1969a) and accentuated turnover of a variety of cellular materials (cf. Billing, Barbiroli \& Smellie, 1969b). Moreover, after interaction with specific hormones in a given target cell, rapid translocation of lysosomes to the nucleus may result in intranuclear liberation of hydrolases, including a variety of nucleases and proteases (Szego, 1970, 1971b; Smith \& Szego, 1971 ; C. M. Szego, B. J. Seeler \& R. A. Steadman, unpublished work). In turn, this phenomenon may provide the long-sought signals (see also Allison \& Mallucci, 1964; Hirschhorn \& Hirschhorn, 1965) for hormonal facilitation of de-repression processes. The fuller significance of lysosomal surface activation for resolution of the nature of steroid hormone action remains to be explored.

This study was aided by research grants CA 01488, HD 04354 and 1-SO5-FR7009 (U.S. Public Health Service) and nos. 473 and IN-3K (American Cancer Society), and by General Research funds of the University of California. Expert assistance in general laboratory services was provided by Miss Tawn Wineland, Miss Namy Iijima and Mr Jan Stehlik. Mr James Previdi, Mr Richard Huber and $\mathrm{Mr}$ Eugene Kaufmann contributed skilled animal care. Capable bibliographic assistance was rendered by Mrs Jona Huefe, Mrs Kathleen Hashiguchi and Miss Barbara Ream.

\section{REFERENCES}

Allison, A. C. (1968). Adv. Chemother. 3, 253.

Allison, A. C. \& Mallucci, L. (1964). Lancet, ii, 1371.

Appelmans, F., Wattiaux, R. \& de Duve, C. (1955). Biochem. J. 59, 438.

Barnard, E. A. (1969). A. Rev. Biochem. 38, 677.

Barondes, S. H. \& Nirenberg, M. W. (1962). Science, N.Y., 138, 810.

Bessey, O. A., Lowry, O. H. \& Brock, M. J. (1946). J. biol. Chem. 164, 321.

Beyler, A. L. (1952). Ph.D. Thesis: University of California, Los Angeles.

Beyler, A. L. \& Szego, C. M. (1954). Endocrinology, 54, 334.
Billing, R. J., Barbiroli, B. \& Smellie, R. M. S. (1969a). Biochim. biophys. Acta, 190, 52.

Billing, R. J., Barbiroli, B. \& Smellie, R. M. S. (1969b). Biochim. biophys. Acta, 190, 60.

Burton, K. (1956). Biochem. J. 62, 315.

Campbell, D. M. \& Moss, D. W. (1961). Clinica chim. Acta, 6, 307.

Catchpole, H. R. (1966). Fedn Proc. Fedn Am. Socs exp. Biol. (Symp.), 25, 1144.

de Duve, C. \& Wattiaux, R. (1966). A. Rev. Physiol. 28, 435.

de Duve, C., Wattiaux, R. \& Wibo, M. (1962). Biochem. Pharmac. 9, 97.

Dingle, J. T. \& Barrett, A. J. (1969). Proc. R. Soc. B, 173, 85.

Dingle, J. T. \& Fell, H. B. (Eds.) (1969). Lysosomes in Biology and Pathology, parts 1 and 2. New York: John Wiley and Sons Inc.

Dougherty, T. F. (1954). Prog. Allergy, 4, 319.

Duncan, C. J. (1966). Nature, Lond., 210, 1229.

Emanuel, C. F. \& Chaikoff, I. L. (1957). Biochim. biophys. Acta, 24, 254.

Fell, H. B. (1969). Ann. rheum. Dis. 28, 213.

Fishman, W. H. (1963). In Methods of Enzymatic Analysis, p. 869. Ed. by Bergmeyer, H. U. New York: Academic Press Inc.

Fishman, W. H. \& Fishman, L. W. (1944). J. biol. Chem. $152,487$.

Fishman, W. H., Goldman, S. S. \& DeLellis, R. (1967). Nature, Lond., 213, 457.

Freinkel, R. K. (1963). In Advances in Biology of Skin, vol. 4: The Sebaceous Glands, p. 125. Ed. by Montagna, W., Ellis, R. A. \& Silver, A. F. New York: Pergamon Press Inc.

Griffin, D. M. \& Szego, C. M. (1968). Life Sci. 7 (II), 1017. Hechter, O. (1955). Vitams Horm. 13, 293.

Hechter, O. \& Halkerston, I. D. K. (1964). In The Hormones, vol. 5, p. 697. Ed. by Pincus, G., Thimann, K. V. \& Astwood, E. B. New York: Academic Press Inc. Hirsch, H. E. (1968). J. Neurochem. 15, 123.

Hirschhorn, K. \& Hirschhorn, R. (1965). Lancet, i, 1046.

Kandutsch, A. A. \& Russell, A. E. (1960). J. biol. Chem. 235, 2253.

Levvy, G. A., McAllan, A. \& Marsh, C. A. (1958). Biochem. $J .69,22$.

Lloyd, J. B. (1969). Biochem. J. 115, 703.

Lowry, O. H., Rosebrough, N. J., Farr, A. L. \& Randall, R. J. (1951). J. biol. Chem. 193, 265.

Moroney, M. J. (1957). Facts from Figures. London: Penguin Books Ltd.

Musa, B. U., Doe, R. P. \& Seal, U.S. (1965). J.biol.Chem. $240,2811$.

Razzell, W. E. (1967). Experientia, 23, 321.

Roberts, S. \& Szego, C. M. (1953). Physiol. Rev. 33, 593.

Scheib, D. (1963). In Ciba Found. Symp.: Lysosomes, p. 264. Ed. by de Reuck, A. V. S. \& Cameron, M. P. London: J. and A. Churchill Ltd.

Smith, R. E. \& Fishman, W. H. (1969). J. Histochem. Cytochem. 17, 1.

Smith, R. E. \& Henzl, M. R. (1969). Endocrinology, 85, 50.

Smith, R. E. \& Szego, C. M. (1971). Proc. 53rd Meet. Endocrine Society, San Francisco (in the Press). 
Szego, C. M. (1957). In Physiological Triggers and Discontinuous Rate Processes, p. 152. Ed. by Bullock, T. H. Washington: American Physiological Society.

Szego, C. M. (1965). Fedn Proc. Fedn Am. Socs exp. Biol. (Symp.), 24, 1343.

Szego, C. M. (1970). Proc. 3rd int. Cong. Hormonal Steroids, Hamburg; Excerpta med. int. Cong.Ser.no. 210 , p. 32.

Szego, C. M. (1971a). In The Sex Steroids: Molecular Mechanisms. Ed. by McKerns, K. W. New York: Appleton-Century-Crofts (in the Press).

Szego, C. M. (1971b). Symp. 3rd int. Cong. Hormonal Steroids; Excerpta med. int. Cong. Ser. (in the Press).

Szego, C. M. \& Davis, J. S. (1967). Proc. natn. Acad. Sci. U.S.A. 58, 1711.

Szego, C. M. \& Davis, J. S. (1969a). Molec. Pharmac. 5, 470.

Szego, C. M. \& Davis, J. S. (1969b). Life Sci. 8 (I), 1109.

Szego, C. M. \& Roberts, S. (1953). Recent Prog. Horm. Res. 8, 419.
Vignais, P. M. \& Nachbaur, J. (1968). Biochem. biophys. Res. Commun. 33, 307.

Weissmann, G. (1965a). New Engl. J. Med. 273, 1084.

Weissmann, G. (1965b). New Engl. J. Med. 273, 1143.

Weissmann, G., Hirschhorn, R., Pras, M., Sessa, G. \& Bevans, V. A. H. (1967). Biochem. Pharmac. 16, 1057. Weissmann, G. \& Thomas, L. (1963). J. clin. Invest. 42, 661 .

Weissmann, G. \& Thomas, L. (1964). Recent Prog. Horm. Res. 20, 215.

Wigglesworth, V. B. (1964). Adv. Insect Physiol. 2, 247.

Woessner, J. F., jun. (1965). Biochem. J. 97, 855.

Woessner, J. F., jun. (1969). In Lysosomes in Biology and Pathology, part 1, p. 299. Ed. by Dingle, J. T. \& Fell, H. B. New York: John Wiley and Sons Inc.

Yonetani, T. (1965). J. biol. Chem. 240, 4509.

Zomzely, C. E., Roberts, S., Gruber, C. P. \& Brown, D. M. (1968). J. biol. Chem. 243, 5396. 